\title{
Investigation of Drainage Structures In The Karst Aquifer System Through Turbidity Anomaly, Hydro Geochemical And Stable Isotope Analyzes (Kiyan Springs, Western Iran)
}

Vahed Kiyani

Tarbiat Modares University

Abbas Esmaili ( $\square$ esmaili@modares.ac.ir)

Tarbiat Modares University

Farshad Alijani

Shahid Beheshti University

Saeideh Samani

Islamic Republic of Iran Ministry of Energy

Research Article

Keywords: Hydrochemistry, Stable isotopes, Turbidity, Kiyan karst springs, composite diagrams

Posted Date: August 9th, 2021

DOI: https://doi.org/10.21203/rs.3.rs-705957/v1

License: (c) (i) This work is licensed under a Creative Commons Attribution 4.0 International License. Read Full License 


\section{Abstract}

Karst aquifers typically have desirable physicochemical properties and can provide an important source of groundwater for drinking. Kiyan karst springs, located in the geological region of the Zagros (western Iran), consist of two springs (Keder and Zolal) situated 3 meters apart. The water of Zolal spring is always clear, with no turbidity during rainfall or earthquake phenomena, but Keder spring, which also provides drinking water to a city of 10,000 inhabitants (Kiyan city), has very high turbidity in these conditions, and this disrupts the drinking water supply for about 1 month per year in the study area. The interpretation of discharge time series diagrams, precipitation, and turbidity in different rainfall and earthquake conditions, composite diagrams, and stable isotope concentrations shows this study area to be a well-developed karst environment with ahighlyeroded tectonic zone and large karst conduits along with turbulent water flow. In general, the difference in the behavior of the two springs is related to different paths of water movement through the drainage area.The two springs share the same source of recharge from rainfall and the same initial underground drainage path from the largest sinkhole in the region; although the path of water movementis divided into two branches, with Zolal spring water entering a narrower fault channel. In the Zolal spring pathway, a siphon-shaped reservoir is formed where muddy rainwatersettles, so that the water from this spring is clear but hashigher concentrations of all ions analyzed here than Keder spring water.

\section{Introduction}

Humans have always been dependent on water, but currently climate change, excess withdrawal and contamination are threats to groundwater such as karst aquifers (Amiletet al. 2020). Karst aquifers provide the water supply for hundreds of millions of people, accounting for $25 \%$ of the world's drinking water, and 35\% of the drinking water in Iran (Ford and Williams2007). Thanks to their favorable physicochemical characteristics, karst aquifers can accumulate large quantities of groundwater, much of which is used as drinking water in Iran and more country (Vasić et al, 2020; Kiyani, 2021). However, drinking water is frequently contaminated by turbidity in karst springs (Massei al. 2006). Lacroix et al. (2000) noted that during recharge periods, particles infiltrate aquifers either diffusely through the soil (autogenic recharge) or concentrated in swallow holes (allogenic recharge).Turbidity can be classified as primaryor secondary, and as allochthonous or autochthonous. Primary turbidity is observed during or after a rainfall event, together with increased discharge. A secondary turbidity peak can be observed many days later during the period of decreasing discharge without rainfall (Lacroix et al. 2000). Amraoui et al (2003) indicated secondary turbidity peak arrived many days later after decreasing discharge and without rainfall and they originates from infiltration of sediments into sinkholes (allochthonous turbidity). In the other hand turbidity may be either allochthonous or result from remobilization of sediments inside the aquifer (autochthonous), including mineral particles (Amraoui et al. 2003).Turbidity is useful indicator of contaminations in karst springs (White et al, 2018). The relationship between discharge, turbidityand contamination is ambiguous in karst spring:turbidity involves a complex of particle types from different direct and indirect sources (Schiperskiet al. 2016; White et al. 2018).

Understanding hydrological systemscan be challenging in the field of groundwater management, due to the lack of hydrological information (Clark 2015). Owen (2016) recommended hydro geochemical approaches and isotopic properties of groundwater as aquifer quality indicators. The use of stable isotopes as natural tracers contributes to the effective management of karst waters. In addition, some researchers have proposed the use of simple indicators such as dissolved oxygen, discharge, turbidity, and electrical conductivity to identify periods of contamination in karst springs (Pronket al. 2006).Monitoring water level, spring discharge and water quality (turbidity and spring hydrochemistry) are thus key factors in karst research (Bakalowicz 2005).

Climate change is one of the critical factors that causes spring discharge attenuation) He et al. 2019(.Statistical relationships between turbidity and geological features in karst springs are highly site-specific and need to be locally calibrated for each karst basin (White et al. 2018). Water level of the spring acts as a natural piezometer, and also provides information about the overall dynamics of the system. Physicochemical evolution can indicate the behavior of karst springs, although sinkhole dynamics do not reflect the observed hydraulic variations (Masseiet al. 2006); In the other hand system behaves linearly with respect to mass transport from the surface (sinkhole) to the spring, with hydraulic standpoint extremely non-linear.

All studies to date conclude that turbidityresponses can be highly variable even within the same system, depending on which processes are involved. The process of exogenous turbidity generation depends on compound of rocks and mount of sinkholes in the drainage basin.

Surface water may contain organic particles such as fecal bacteria, organic matter, or chemical compounds such as nitrates and other phytosanitary products (Savary et al. 2021).Also Lateral flow on the subsurface to preferential recharge areas such as sinkholes result in concentrated infiltration that bypasses the soil(Pronk et al, 2006), and contaminants (soil...) can move unimpeded from recharge areas (sinkholes) to the water-supply extraction area (White et al, 2018).Hydrological compartments interact through network of fractures and faults and it is connections between the surface and deep levels of karts aquifer too (Bicalho, 2016).Karst aquifers are prone to high pollution due to fast water transfer channel structures. In this kind of aquifer,untreated pollutants flow through sinkholes and submerged rivers, rapidly enter karst aquifers, and subsequently appear downstream in karst springs. It should be noted that the complex karst structures and different movement paths within the karst make it difficult to interpret the water quality of karst aquifers and springs (Field 2021).some heavy metal such as arsenic,... have above concentration in Karst spring; Simsek et al (2008) stated that elevated arsenic concentrations were related to local geologic 
formations which are likely to contain oxidized sulfite minerals in clay stones. In Ireland (McGrory et al, 2016) a national-scale research assessment of groundwater identified isolated clusters of elevated arsenic and indicated that lithology was a major controlling factor on arsenic in groundwater too.Nasrabadi and Bidabadi (2013) mentioned existence of volcanic activities within the upper Miocene and Pleistocene in study area (western Iran) may be addressed as the main geopogenic source of arsenic pollution. Significant differences between different aquifer litho logy, indicating that sandstone, shale and Limestone; and locally important fractured bedrock aquifers presenting high risk of arsenic too (McGroryet al, 2016). Karst aquifers are highly susceptible to the transfer of pollutants, especially turbidity, and the presence of highly turbid water is one of the characteristics of karst aquifers. The origin of the turbidity process in karst can be explained by characterizing the physical mechanisms. In karstic aquifers with porous environments and unsaturated zone systems, water has the opportunity to be filtered before entering the aquifer environment; hence in this aquifer type, turbidity phenomena rarely occur. When the karst system is developed, turbidity that enters the aquifer can come from two completely different sources. One is exogenous turbidity, which originates externally and enters the karst aquifer from runoff outside the basin. The other source is endogenous turbidity resulting from sedimentary deposits within the aquifer itself. To determine whether the source of turbidity is rainfall or not, it is necessary to carefully examine the relationship between rainfall and turbidity (Savary et al. 2021).During the increased flow rate instability in the chaotic regime that was represented by suspended matter, which was evacuated independent of the discharge rate and the sediment is evacuated towards the outlet in waves of turbidity; which must be control before drinking by karstic water treatment stations (Bouchaouet al, 2002).

The aim of the present study is to improve our knowledge of the hydro geological system of Kiyan karst springs by using hydro geochemical information and stable isotopes, and by identifying the reasons for turbidity anomalies that appear with sudden increases in discharge. For this purpose, physicochemical data (electrical conductivity, total dissolved solids, $\mathrm{pH}$, dissolved oxygen, turbidity, and water temperature), main ions,some heavy metal and stable isotopes of oxygen 18 and deuterium were analyzed. This study is the first report, to our knowledge, that provideshydro geochemical and stable isotope data for the karst springs in the study region. The discharge data were obtained for two springs:Zolal and Keder. By plotting the recession curve of the springs, calculating the dynamic storage volume of the reservoirs, determining the alpha coefficient, and finally examining isotopic and chemical results, the hydrogeology of these two karst springs and their underground drainage systemswere characterized in detail, and possible reasons for the turbidity of Keder spring were identified.Any way this study yielded important results for understanding the karst water system in the study area and can be used for comparing with similar situation in every karst study.

\section{The Study Area}

The Kiyan springs are located in the Gamasiyab Basin withinthe Zagros Zone(Garin Mountains) in western Iran(Fig. 1)and compriseKeder and Zolal springs. The distance between these two karst springs ranges from 1 to $5 \mathrm{~m}$ (mean $3 \mathrm{~m}$ ). The springs have been supplying irrigation and drinking water to the area of Kiyan city for approximately 5700 years (since 3700 years BCE) (Gerishman et al.1939).

The discharges of Keder and Zolal springs increased abruptly on 5 May 2019, in the absence of stresses such as earthquake or storm events. During this period of increased discharge, the turbidity of Keder spring increased, whereasZolal spring water remained clear. Zolal spring water is always clear during and after earthquake events and prolonged rainfall, but Keder spring is characterized by heavy turbidity during and after these phenomena. The water discharged fromKeder spring $(60 \mathrm{~L} / \mathrm{s})$ supplies drinking water for 10,000 people in Kiyan city. The different behaviors of the two springs pose an interesting phenomenon for scientific research, and we hope that discovering the reasons for the transient turbidity of Keder spring will help to find a solution for this problem in the future.

\subsection{Geological and hydro geologicalsetting}

Iran is divided into five major geological zones: Zagros, Sanandaj-Sirjan, East and Southeast, Central Iran, and Alborz. Western Iran is comprised of major mountain chain, the Zagros Fold and Thrust Belts. Zagros zone is separated from the Central zone by the narrower Sanandaj-Sirjan metamorphic zone. Geomorphologic investigations have found clear differences between the extentand intensity of karst surface landform development and have being abundant karst spring especially in Zagros zone. (KarimiVardanjani et al, 2017). The study area located in Zagros zone. The research area covers approximately 9800 hectares, and is characterized by two karstic springs. TheseKiyan springs discharge from orbitoline-containing limestone dating from the Cretaceous and located between the $\mathrm{K}^{1} \mathrm{~m}$ and $\mathrm{K}^{1} \mathrm{v}^{1}$ contact unit as a thrust fault.The $\mathrm{K}^{\mathrm{l}} \mathrm{v}^{1}$ unit (pyroclastic rocks) is mixed with crystalline limestones and fragments of volcanic rocksas TRjvm unit (Fig. 1). TRjvm unit consist of interbedded metavolcanics(lava flows and tuffs)and thin bedded,well foliated marbles with thin,upward increasing slate layers. This area is composed mainly of Mesozoic carbonate with layers of light gray, well-bedded limestones interbedded with marly, orbitoline-bearing limestones, and subordinate volcanic rock from the Cretaceous. Erosion and dissolution along the axis of the syncline led to the formation of the semi-aridKiyanSpring Valley(Fig. 2), according to research by Ashjari and Raeisi (2006). Geomorphology of this area consists of a plane (about $80 \mathrm{~km}^{2}$ ) with many sinkholes; The Kiyan springs lie at the junction of a northeast-trending thrust fault (Figs. 1 and 3) and a northwest-trending cross strike fault.AlsoZolal and Keder springs are according to major (active) and minor (nonnatives) faults respectively;thisspring's located in path of faults and tectonic fractures (Fig. 1) 
The largest sinkhole in the study area,locally named the Gachal sinkhole and located in the northwest of the Kiyan watershed, has an area of about 800 hectares and is situated in the $\mathrm{K}^{11} \mathrm{~m}$ limestone unit witha depth of more than $200 \mathrm{~m}$ according to field observations (Fig. 2). The sinkhole is at an altitude of $2815 \mathrm{~m}$ above sea level, and the springs are situated $1715 \mathrm{~m}$ above sea level, so the difference in altitude between the potentialrecharge(sinkhole) and discharge sites (springs) is $1100 \mathrm{~m}$ over a distance of $6 \mathrm{~km}$ from the dolinesto the springs.According to synoptic meteorological data for Nahavand city (Meteorological Organization of Iran), the average annual rainfall in the Kiyan catchment area is $500 \mathrm{~mm}$.

Figure 4 shows the turbidity of the Keder spring after the 2017 earthquake and 2018 rainfall. As can be seen, the Keder and Zolal springs are about $3 \mathrm{~m}$ apart (i.e., in close proximity to each other). The turbidity caused by precipitation and earthquakes is completely different in terms of color, origin, appearance, type, and amount of sediments (Fig. 4).

\subsection{Condition of the alluvial aquifer adjacent to Kiyan Karst area}

A karst aquifer can affect an adjacent alluvial aquifer and vice versa if there is a hydraulic connection between them through a fracture or fault.However, if these two sources are not connected, karst and alluvial aquiferscan differ in their properties.

Groundwater levels in the observation wells nearest to Kiyan karst springs are presented in Table 1.Average groundwater level in the study area is $13.8 \mathrm{~m}$. The exploitation well in the alluvial aquifer nearestto the karst area is more than $5 \mathrm{~km}$ away,and the Kiyan springs are located $250 \mathrm{~m}$ higher than the alluvial aquifer.The increasing trend in water level in observation(pizometric) wells from March 2019 (Table 1) illustrates the recharge of alluvial aquifers from the karst area.

Table 1

Groundwater level (m) of pizometric wells nearest to Kiyan karst springs in water-year 2018-2019

\begin{tabular}{|c|c|c|c|c|c|c|c|c|c|c|c|c|c|c|}
\hline Well name & $\begin{array}{l}\text { UTM } \\
\text { (x) }\end{array}$ & UTM (y) & $\begin{array}{l}\text { Sept } \\
2018\end{array}$ & $\begin{array}{l}\text { Oct } \\
2018\end{array}$ & $\begin{array}{l}\text { Nov } \\
2018\end{array}$ & $\begin{array}{l}\text { Dec } \\
2018\end{array}$ & $\begin{array}{l}\text { Jan } \\
2019\end{array}$ & $\begin{array}{l}\text { Feb } \\
2019\end{array}$ & $\begin{array}{l}\text { Mar } \\
2019\end{array}$ & $\begin{array}{l}\text { Apr } \\
2019\end{array}$ & $\begin{array}{l}\text { May } \\
2019\end{array}$ & $\begin{array}{l}\text { June } \\
2019\end{array}$ & $\begin{array}{l}\text { July } \\
2019\end{array}$ & $\begin{array}{l}\text { Aug } \\
2019\end{array}$ \\
\hline Hoseinabad & 249497 & 3784016 & 10 & 10.78 & 9.23 & 8.16 & 7 & 13.54 & 15.16 & 16.6 & 16.12 & 17.1 & 16.29 & 17.1 \\
\hline Miyanabe & 244650 & 3785080 & 10.4 & 13.96 & 13.43 & 11.52 & 9.54 & 14.24 & 15.46 & 16 & 16.8 & 17.6 & 17.22 & 17.7 \\
\hline
\end{tabular}

\section{Material And Methods}

Recognizing whether the recharge path drains exclusively via a canalized system and through karstic layers or not requires the preparation of a hydrograph and a recession curve.Analysis of the hydrographs was used to determine the amount of karstification and to trace water passage paths in the two springs. In carbonate areas, the characteristics of karst springs can be determinedby investigating changes in discharge, water quality, and temperature. Among the techniques to study karst springs are calculating their dynamic storage volume, investigating the drying time, calculating the recession curve and recession coefficient, and investigating quantitative and qualitative changes in the concentration of isotopes and other chemicals in spring water. The Maillet experimental formula can be used to calculate the alpha coefficient (discharge reduction coefficient) (Maillet 1905). In this formula, the discharge coefficient is expressed as the tangent of the angle between the recession line and the horizontal axis.

$a=\frac{\log \frac{Q_{0}}{Q_{t}}}{0.4343(t)}$

Dynamic storage volume, a factor dependent on specific geological conditions and feedback from the karst development in a given area, can be obtained with the following equations:

$v=\frac{\left(Q_{0} * 86400\right)}{a}$
$t_{0}=\frac{t * \log e}{\log \frac{Q_{0}}{Q_{t}}}$

Where $Q_{0}$ is the primary discharge calculated from the recession curve, $Q_{t}$ is the secondary discharge in the recession curve at a point located at distance $t$, vis the dynamic storage, $t_{0}$ is the spring drainage time assuming a discharge of $Q_{0}$, and $t$ is the time between primary and secondary discharge.

To evaluate the water quality of springs in this study, electrical conductivity, temperature, total dissolved solids (TDS), and pH were measured with a multimeter device (model HQ40d,Hach)and turbidity was measured with a turbidity meter (model 2100N, Hoch).Discharge was measured with a volumetric and flowmetric method at the site. Nitrate, nitrite, chloride, fluoride, and sulfate concentrations weremeasured with a DR-5000 device 
(Hach) according to standard methods, and carbonate and bicarbonate concentrations were determined with a titration method (with $0.02 \mathrm{~N}$ hydrochloric acid, pH approximately 4.5) One day after sample collection,these analyses were done atthe water laboratory of Nahavand city (Iran). Concentrations of sodium, potassium, calcium, barium, arsenic, manganese, cobalt, nickel, copper, zinc and ferric were also measured by inductively coupled plasma mass spectrometry (ICP-OES, SPECTRO, Kleve, Germany)at the University of Tehran (Iran).

Before the analysis of stable isotopes, samples with high turbidity were diluted at a rate of $1 \mathrm{~ms} / \mathrm{cm}$ with $0.45 \mu \mathrm{m}$ paper filter, then stable isotopes $\delta^{18} \mathrm{O}$ and $\delta^{2} \mathrm{H}$ were analyzed by laser spectrophotometry (Liquid Water Isotope Analyzer LWIA-24d) at a precision of $\pm 2 \%$ in the laboratory of the Atomic Energy Organization of Iran. Isotopic data were corrected according to the Vienna Standard Mean Ocean Water (VSMOW).

Samples of spring water were collected twice a year and alsoon different days during the sudden turbidity episode, by judgmental sampling (Table 7). In the judgmental method (Zhang, 2007), sensitive areas (e.g. drinking water) are sampled. Because Keder spring water is used for drinking and turbidity is a major issue in this spring, turbidity was analyzed during the 2017 earthquake, precipitation in 2018 , the phenomenon of a sudden increase in turbidity in 2019, and during precipitation in 2020. Sampling was performed twice in the 2018-2019 wateryears in the dry season (mid-October 2018) and the wet season (mid-April 2019) to measure physicochemical properties, stable isotopes, and turbidity anomalies.

Table 7

Turbidity of Keder spring after earthquake, precipitation and turbidity phenomenon

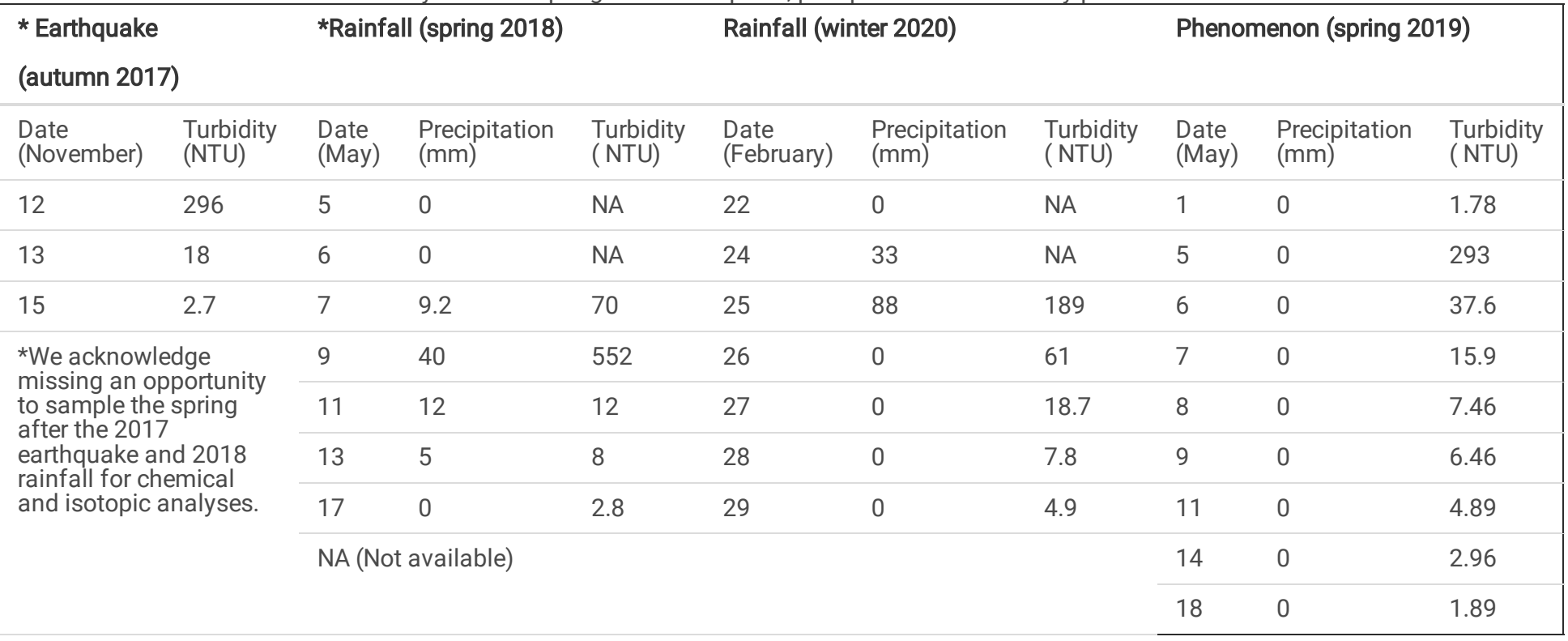

Because both discharge and turbidity increased abruptly on 5 May 5 2019, a series of samples collected on this date were analyzed to measure the physical and chemical properties and stable isotopes $\left(\delta^{18} \mathrm{O}\right.$ and $\left.\delta^{2} \mathrm{H}\right)$. A total of 73 samples Kiyansprings water were tested, as shown in Table 2. The calculated parameters and analyzed data from both Zolal and Keder karst springs are presented in Tables3, 4 and 5.

Table 2

Sample amount and type of analysis

\begin{tabular}{|c|c|c|c|}
\hline Spring name & Sample amount & Analysis type & Date/Season/occasion \\
\hline \multirow[t]{3}{*}{ Keder } & 28 Sample & Turbidity & $\begin{array}{l}\text { Earthquake } 2017 \text {, Wet \& dry season } 2018-2019 \text {, } \\
\text { phenomena } 2019 \text { and storms } 2018 \text { \& } 2020\end{array}$ \\
\hline & 17 Sample & Physicochemical & Wet \& dry season 2018-2019, phenomena 2019 and storm 2020 \\
\hline & 10 Sample & stable isotopic & Wet \& dry season 2018-2019 and phenomena 2019 \\
\hline \multirow[t]{3}{*}{ Zolal } & 9 Sample & Turbidity & Wet \& dry season 2018-2019, phenomena 2019 and storm 2020 \\
\hline & 9 Sample & Physicochemical & Wet \& dry season 2018-2019, phenomena 2019 and storm 2020 \\
\hline & 2 Sample & Stable isotopes & Wet season 2018-2019 and phenomena 2019 \\
\hline
\end{tabular}


Table 3

Physicochemical and stable isotope data forKiyan springs

\begin{tabular}{|c|c|c|c|c|c|c|}
\hline \multirow[t]{2}{*}{ Parameter / Ion } & \multicolumn{3}{|l|}{ Kederspring } & \multicolumn{3}{|l|}{ Zolal spring } \\
\hline & October 2018 & April 2019 & 5 May 2019 & October 2018 & April 2019 & 5 May 2019 \\
\hline Discharge $\pm 10 \%$ & 1314 & 2804 & 3642 & 87 & 130 & 243 \\
\hline Turbidity (NTU) & 0.72 & 1.78 & 293 & 0.43 & 0.86 & 1.23 \\
\hline C) $\pm 0.1^{\circ}$ Temperate ( & 14.5 & 14.4 & 14.2 & 15.1 & 18.3 & 14.9 \\
\hline $\mathrm{pH} \pm 0.1$ & 8.13 & 8.2 & 7.8 & 8.41 & 7.63 & 9.76 \\
\hline $\mathrm{EC}(\mu \mathrm{c} / \mathrm{cm}) \pm 1$ & 249 & 200.1 & 244 & NA & 243 & 225 \\
\hline TDS (mg/L) & 138.2 & 124.9 & 134.1 & NA & 133.7 & 134.2 \\
\hline DO & 9.1 & 6.32 & 3.15 & 7.8 & 6.96 & 8.38 \\
\hline $\mathrm{Cl}$ & 8.5 & 9 & 1.3 & NA & 14.18 & 3 \\
\hline $\mathrm{F}$ & 0.5 & 0 & NA & NA & NA & 0.03 \\
\hline $\mathrm{SO}_{4}$ & 0 & 0 & 3.517 & NA & 0.29 & 1.91 \\
\hline $\mathrm{Co}_{3}$ & 0 & 0 & 0 & 0 & 0 & 0 \\
\hline $\mathrm{HCO}_{3}$ & 140 & 116 & NA & NA & 128.14 & 56 \\
\hline $\mathrm{Ca}$ & 34 & 16.657 & 18.186 & NA & 32.06 & 12.67 \\
\hline $\mathrm{Mg}$ & 8.4 & 2.685 & 3.272 & NA & 10.93 & 3.988 \\
\hline $\mathrm{Na}$ & 8.28 & 1.577 & 1.784 & NA & 7.59 & 2.164 \\
\hline K & 0.39 & 0.0433 & 0.0792 & NA & 0.39 & 0.0545 \\
\hline Total hardness & 119.5 & 120 & 58.885 & NA & 125.1 & 48.06 \\
\hline Alkalinity & 140 & 60 & 78 & NA & 128.14 & 56 \\
\hline $\mathrm{Fe}(\mu \mathrm{g} / \mathrm{l})$ & 39.5 & 11.676 & 434.823 & 20.8 & NA & 62.651 \\
\hline As & 19.1 & 8.334 & 11.272 & NA & NA & 24.068 \\
\hline Co & $<0.043$ & $<0.043$ & 0.305 & NA & NA & $<0.043$ \\
\hline $\mathrm{Cu}$ & 24.8 & 0.457 & 4.65 & NA & NA & $<0.306$ \\
\hline $\mathrm{Zn}$ & 181.6 & 2.116 & 22.609 & NA & NA & 4.129 \\
\hline $\mathrm{Ni}$ & 2.7 & $<0.286$ & 5.455 & NA & NA & $<0.286$ \\
\hline $\mathrm{Mn}$ & 1.7 & 0.355 & 29.345 & NA & NA & 6.637 \\
\hline $\mathrm{Ba}(\mu \mathrm{g} / \mathrm{L})$ & 13.7 & 5.338 & 12.404 & NA & NA & 8.06 \\
\hline$\delta^{18} \mathrm{O}(\%$ vs. SMOW) & $-7.06 \pm 0.24$ & $-6.54 \pm 0.21$ & $7.14 \pm 0.13-$ & $-7.16 \pm 0.23$ & NA & $-7.09 \pm 0.33$ \\
\hline$\delta^{2} \mathrm{H}$ (\%o vs. SMOW) & $-41.62 \pm 0.62$ & $-43.12 \pm 0.94$ & $-32.99 \pm 0.85$ & $-42.19 \pm 0.75$ & NA & $-39 \pm 0.82$ \\
\hline
\end{tabular}


Table 4

Physicochemical and stable isotopic data of Keder spring on 5 May 2019 phenomena

\begin{tabular}{|c|c|c|c|c|c|c|c|c|c|}
\hline $\begin{array}{l}\text { Day } \\
\text { (May) }\end{array}$ & $\begin{array}{l}\text { Discharge } \\
(1 / s)\end{array}$ & $\begin{array}{l}\text { Turbidity } \\
\text { (NTU) }\end{array}$ & $\begin{array}{l}\text { Temperate } \\
\left({ }^{\circ} \mathrm{C}\right)\end{array}$ & $\begin{array}{l}\text { TDS } \\
(\mathrm{mg} / \mathrm{l})\end{array}$ & $\begin{array}{l}E C \mathrm{c} / \mathrm{cm}) \\
\mu(\end{array}$ & $\mathrm{pH}$ & $\begin{array}{l}\text { DO } \\
(\mathrm{mg} / \mathrm{l})\end{array}$ & $\begin{array}{l}\delta^{18} 0 \\
\text { (\%o vs. } \\
\text { SMOW) }\end{array}$ & $\begin{array}{l}\delta^{2} \mathrm{H} \\
\text { (\%o vs. } \\
\text { SMOW) }\end{array}$ \\
\hline 1 & 2804 & 1.78 & 13 & 124.9 & 200.1 & 7.74 & 7.96 & $-6.54 \pm 0.21$ & $-43.12 \pm 0.94$ \\
\hline 5 & 3642 & 293 & 14.2 & 134.1 & 244 & 7.8 & 7.88 & $-7.14 \pm 0.13$ & $-32.99 \pm 0.85$ \\
\hline 6 & 3051 & 37.6 & 15.4 & 126.8 & 225 & 6.36 & 7.53 & $-7.02 \pm 0.27$ & $-33.98 \pm 0.74$ \\
\hline 7 & 2998 & 15.9 & 12.6 & 127.8 & 202.7 & 6.91 & 7.9 & $-6.44 \pm 0.43$ & $-43.3 \pm 0.74$ \\
\hline 8 & 2984 & 7.46 & 12.3 & 127.1 & 200.3 & 9.36 & 8.75 & $-6.24 \pm 0.17$ & $-44.49 \pm 0.84$ \\
\hline 9 & 2957 & 6.46 & 12.5 & 128.2 & 202.8 & 9.99 & 8.58 & $-6.92 \pm 0.32$ & $-36.64 \pm 0.88$ \\
\hline 11 & 2860 & 4.89 & 12.5 & 126.6 & 200.3 & 9.46 & 7.58 & $-6.78 \pm 0.13$ & $-38 \pm 0.82$ \\
\hline 14 & 2635 & 2.96 & 14.1 & 130.7 & 225 & 8.3 & 8.18 & $-6.59 \pm 0.3$ & $-39.91 \pm 0.64$ \\
\hline 18 & 2498 & 1.89 & 13.2 & 128.1 & 206.4 & 9.57 & 7.98 & $-6.4 \pm 0.09$ & $-42.43 \pm 0.81$ \\
\hline
\end{tabular}

Table 5

Physicochemical data of Keder \& Zolal springs on rainfall 25 February 2020

\begin{tabular}{|c|c|c|c|c|c|c|c|c|c|c|c|c|c|c|}
\hline \multirow{2}{*}{$\begin{array}{l}\text { Day } \\
\text { (February) }\end{array}$} & \multicolumn{2}{|c|}{ Discharge (l/s) } & \multicolumn{2}{|c|}{ Turbidity (NTU) } & \multicolumn{2}{|c|}{ Temperate $\left({ }^{\circ} \mathrm{C}\right)$} & \multicolumn{2}{|c|}{ TDS (mg/l) } & \multicolumn{2}{|c|}{$\mathrm{EC}(\mu \mathrm{c} / \mathrm{cm})$} & \multicolumn{2}{|l|}{$\mathrm{pH}$} & \multicolumn{2}{|c|}{$\mathrm{DO}(\mathrm{mg} / \mathrm{l})$} \\
\hline & Keder & Zolal & Keder & Zolal & Keder & Zolal & Keder & Zolal & Keder & Zolal & Keder & Zolal & Keder & Zolal \\
\hline 22 & 4426 & 276 & 1.9 & 0.9 & 12 & 13 & 138 & 134.2 & 206 & 222 & 7.8 & 8.5 & 8.5 & 8.6 \\
\hline 25 & 5166 & NA & 189 & NA & 12.5 & NA & 118.1 & NA & 167 & NA & 6.53 & NA & 9.74 & NA \\
\hline 26 & 5863 & 366 & 61 & 1.33 & 12.1 & 13.7 & 118.4 & 138.5 & 186 & 225 & 7.78 & 7.66 & 8.94 & 8.59 \\
\hline 27 & 5587 & 349 & 18.7 & 3.24 & 13.6 & 15.5 & 121.5 & 133.4 & 197.5 & 227 & 8.72 & 8.83 & 8.89 & 9 \\
\hline 28 & 5216 & 327 & 7.8 & 1.71 & 12.4 & 14 & 126.3 & 134.4 & 199.3 & 220 & 8.68 & 7.53 & 9.6 & 9.2 \\
\hline 29 & 4438 & 278 & 4.9 & 1.3 & 12.7 & 13.6 & 128.1 & 145.2 & 203.7 & 219.5 & 9.08 & 8.65 & 9.24 & 9.19 \\
\hline
\end{tabular}

\section{Results And Discussion}

The discharge data for Zolal and Keder springs were extracted, and by plotting the recession curve for each spring, the dynamic storage volume of their reservoirs was determined, and the alpha coefficient was calculated.In addition,examining the isotopic chemical characteristics and heavy metalof the springs allowed us to analyze karst development in this study area and identify the likely reasons for the turbidity of Keder spring, as discussed below.

\subsection{Water quantity of springs}

The special conditions of the drainage regime which result from factors such as precipitation regime, lithology, the arrangement of rock layers, and their thickness, texture, and porosity, affect the hydrographic characteristics and recession curve of springs in karst areas compared to other areas. In non-karst or less developed karst areas, springs typically show a downward curve with a uniform linear trend and low alpha content in the recession curve. However, in areas with high karst development, springs either have a linear trend with high alpha content or yield three different linear slopes with different recession coefficients,normally with recession coefficient $a_{1}$ being less than $a_{2}$ and more than $a_{3}$ (Ford, 2007). The alpha coefficient, which indicates the discharge coefficient or the ability to discharge groundwater, expresses the hydro geological characteristics of the area that result from parameters such as porosity and the aquifer transmissivity coefficient. In this framework, the largerthe alpha coefficient is, the higher the slope of the recession curve, and the greaterthe flow discharge,thus indicating the speed of flow discharge from rainfall and the degree of porosity and karstification of the basin. However, in the inverse case, non-karstification or low karstification of the basin is observed. In Fig. 5the recession curves for Zolal and Keder spring discharges are plottedsemilogarithmically against time. The data are from discharges of both springs in 2018 September to 2019 September. Recession curve data are also presented in Table 6. 
Table 6

Coordinates, discharge and dynamic volume reservoir

\begin{tabular}{|lll|}
\hline Attribute & \multicolumn{2}{c|}{ Kiyan springs } \\
\cline { 2 - 3 } & Keder & Zolal \\
\hline Latitude $(\mathrm{X})$ & 243709 & 243715 \\
\hline Longitude $(\mathrm{Y})$ & 3781363 & 3781366 \\
\hline Altitude $(\mathrm{Z})$ & 1715 & 1716 \\
\hline Discharge mean $(\mathrm{I} / \mathrm{s}$ & 1800 & 120 \\
\hline Recession coefficient & 0.04 & 0.04 \\
\hline Type of current & conduit & conduit \\
\hline Dynamic volume reservoir (million $\mathrm{m}^{3}$ ) & 49 & 3.1 \\
\hline To & 158 & 158 \\
\hline
\end{tabular}

The recession coefficient curveshows a completely linear trend for both springs. According to Fig. 5 and Table 6, the recession coefficient (0.04) and drying coefficient (158 days) are equal for both springs, but the dynamic volume of the Kederaquifer (49 million $\mathrm{m}^{3}$ ) is larger than the volume of the Zolal aquifer ( 3 million $\mathrm{m}^{3}$ ); On the other hand dynamic reservoir volume in Keder spring is 16 more times bigger than Zolal spring.

According to Malík and Vojtková, (2012), this alpha value, despite the observation of a linear regime in the recession diagram, represents a karstic area with highly tectonic and permeable areas and conduit flows. This is also evident from the hydrographs of the two karst springs as shown in Fig. 6. Aquifer permeability is so high that rainfall in the region leads to a sudden rise in discharge fromthe springs. For example, average monthly dischargefromZolal spring is $120 \mathrm{~L} / \mathrm{s}$ and average flow fromKeder spring is $1800 \mathrm{~L} / \mathrm{s}$, but during periods of heavy rainfall, discharge reached 243 $\mathrm{L} / \mathrm{s}$ in Zolal spring and $3642 \mathrm{~L} / \mathrm{s}$ in Keder spring.The long-term hydrograph of Keder spring confirms this increase. As shown in Fig. 6 , during the period from 2011 to 2019, increased discharge was associated with an increase in rainfall. Geomorphologic features such as the nearby large sinkhole and high discharge suggest, along with the discharge characteristics, that the KiyanKarst system is well developed and can be said to be similar to the Dinaric Karst system (Stevanović, 2019).

\subsection{Quality of the springs}

To further characterizethe Kiyan karst area, water quality of the two springs was studied. In areas where water infiltration and flow in the aquifer occur via canals and conduits, the extent of contact between water and the different layers and constituents is less than in areas with lower permeability and a diffuse flow regime. As a result, the amount of solutes will be lower and they will show lower electrical conductivity.

In this study area, high turbidity is one of the problems of Keder karst spring. Water turbidity increases in spring because of processes such as heavy rainfall and earthquakes.

However, on 5 May 52019 turbidity increased in the absence of earthquakes or heavy rain. Turbidity in Keder spring takes more than 1 week to completely disappear. It should be noted that Zolalspring, despite being located only $3 \mathrm{~m}$ from Keder spring, remains clear and transparent all year round. To determine the causes of this difference in behavior, informationis needed about the structure of the karst. In the following sections, the structure and characteristics of karst in the study area are reported and discussed in connection with water quality in the two springs.

\subsubsection{Water turbidity}

Turbidity is a property of water that is related to other properties, and different indicators can be used to determine the source of turbidity. Because turbidity is one of the main problems of Keder karst springs in this study area, and because Keder spring water is also as a source of drinking water in the region, the turbidity of Keder springs was analyzed after the 2017 earthquake, 2018 rainfall, 2019 phenomenon, and 2020 rainfall. The results of turbidity analyses are presented in Table 7, and changes in turbidity with time are shown in Fig. 6 , which illustrates the difference between turbidity due to precipitation and due to the earthquake. The latter increased turbidity during a period of reduced discharge, and the turbidity peak can be attributed to the movement of sediments in the walls of karst conduit networks (autochthonous). However, precipitation also increased turbidity during periods of increased discharge, and the origin of these turbidity peaks is related to unfiltered sediments in dissolved holes (ollchthonous). This phenomenon lasted more than 1 week in Kederspring until the water became clear again,whereas Zolal spring had no visible turbidity, and turbidity analyses of water from this spring confirmed the absence of sources of cloudiness (Table 7). The first turbidity peak associated with the 2017 earthquake was $296 \mathrm{NTU}$, the second peak during the 2018 rainfall reached a maximum of 552NTU,after which turbidity decreased graduallyto $2.8 \mathrm{NTU}$ (Table 7). Earthquake caused rising turbidity, it occurred during a period of decreasing flow rates, and turbidity peak can be explained by remobilization of sediment walls inside conduit network (autochthonousturbidity). 
In May 2019 peak turbidity was 293 NTU,and after the 2020 rainfall, maximum turbidity was 189NTU. Toillustrate the effect of rainfall on Keder spring water, daily rainfall in 2018 and 2019 is plotted with turbidity in Fig. 6. In 2018, rain immediately caused turbidity in the spring, and in April 2019 , precipitation was in the form of snow,and turbidity due to snowmelt was delayed by about 1 month, occurring in May 2019 . This finding reflects the developed karst system in theKeder spring, which transmits precipitation directly to the spring outlet through channel flows. Turbidity indicates the presence of rapid groundwater flow with a relatively short transfer in the karst groundwater aquifer (Perez et al. 2013). Discharge and turbidity are correlated, thus the rapid flow of water immediately after rainfall leads to turbidity. Accordingly, spring discharge is considered an indicator of pollution (turbidity) (Amraouiet al. 2003).

The differences between the two springs in turbidity and discharge indicate the presence of a different flow path for Zolal spring. Considering the recession curves for each spring, the high discharge of Keder spring, the tectonic characteristics of the region, and the location of the springs in fault zones, the development of karstification in the region can be assumed to be very high. As a result,Keder spring, where high turbidity occurs, is likely to transmit rainfall via highly fractured routes and large karst canals immediately after rainfall, with little or no infiltration. Part of the turbidity of Keder spring can also be attributed to the movement of wall sediments within the karst conduit networks (autochthonous). The occurrence of turbidity after the earthquake supports confirms this mechanism. The degree of karstification and the presence of faults and fractures along with instability of the fault walls in the tectonic fold zones in the groundwater flow path have a significant effect on water quality in Keder spring. In contrast, Zolal springhas a siphon-shaped reservoir where water accumulates. After precipitation, the new influx of rainwater or snowmelt has an opportunity to settle, as turbid rainwater replaces the existing reservoir water which flows to the spring. For this reason, the water in this spring, unlike the water in Keder spring, remains transparent when it rains.

The next sections compare other parameters of water quality between the two springs.Our results support the suggestion that Zolal spring water reaches the discharge site from a siphon-shaped reservoir. It should be noted, however, that accurate dye tracer tests are needed to accurately diagnose the factors that influence discharge characteristics in each spring.

\subsubsection{Karst status in the study area based on physical, chemical and isotopic analyses}

\subsubsection{Gibbs diagrams}

To identify the mechanismsthat influence water chemistry, a Gibbs diagram (Gibbs 1970) was drawn for water samples (Fig. 9). Gibbs divides the mechanisms that control water chemistry and its evolution into three categories: rock weathering, evaporation, and atmospheric precipitation.

To evaluate the origin of water-soluble chemicals, Gibbs prepared two graphs for the ratio of $\mathrm{Na} /(\mathrm{Na}+\mathrm{Ca})$ and $\mathrm{Cl} /(\mathrm{Cl}+\mathrm{HCO})_{3}$ to $\mathrm{TDS}^{\text {In }}$ samples with high $\mathrm{Na} /(\mathrm{Na}+\mathrm{Ca})$ and $\mathrm{Cl} /\left(\mathrm{Cl}+\mathrm{HCO}_{3}\right)$ ratioswith TDS less than $100 \mathrm{mg} / \mathrm{L}$, precipitation has the greatest effect on water chemistry. Low ratios of $\mathrm{Na} /(\mathrm{Na}+\mathrm{Ca})$ and $\mathrm{Cl} /\left(\mathrm{Cl}+\mathrm{HCO}_{3}\right)$ with TDS between 100 and $1000 \mathrm{mg} / \mathrm{L}$ indicate the effect of rock weathering processes. If both ratios are elevated, evaporation is the main factor controlling water chemistry. According to these diagrams, the main factor controlling water composition in both springs is the weathering process of carbonated rocks.

\subsubsection{Composite diagrams}

Composite diagrams are a useful tool for understanding the different sources of groundwater, and have been used to identify geochemical processes affecting groundwater quality (Mazor 2004). The pattern of points is usually single-cluster, two-cluster, triangular, linear, or scattered, each with its own description according to the two factors $(x, y)$. In the line diagram, if the line fits the points at an angle to the $x$-axis, this indicates the mixing of two types of water, and if the line fits parallel to the $x$-axis, the diagram indicates no mixing. The $x$-axis can be the concentration of total soluble ions or TDS. If the fitted line slopes and intersects the TDS axis, ion content in the water entering the aquifer is less than in the aquifer water. If the fitted line intersects the $y$-axis, the amount of this ion in the water that mixes with the aquifer is greater than in the aquifer. If the fitted line passes through the origin, ion content is the same in both waters, and if the points accumulate in one area of the plot, this reflects a common source of recharge for all samples (Mazor2004).

Figure 10plots TDS versus the concentration of calcium, magnesium, sulfate, and bicarbonate ions in Keder and Zola spring samples. The data for these springs is from samples obtained in October 2018, May 2019, and April 2019 for Keder spring and in October 2018 and May 2019 for Zolal spring. In these diagrams, the water composition of both springs shows the same source, and in all four cases the shape of the plots shows a single cluster (Mazor, 2004). In view of the similar reaction of both hydrographs to spring rainfall, it can be deduced that rainfall provides a direct source of water in both springs. Based on these diagrams, which indicate the same source of recharge for both springs, and because of the proximity of the two springs and the similar behavior of their hydrographs, these two springs likely share the same path of movement in the initial part of their pathways. In the course of the path of water, a small part enters a joint with a narrower duct. In the path of this narrow joint,a siphon

tank structure has formed, and as a result the water discharged by this spring is clear. Most likely, the same source of water entry for both springs is the Gachal sinkhole, i.e. the largest sinkhole in the region.

\subsubsection{Isotopic analysis}


Values of $\delta^{18} \mathrm{O}$ and $\delta^{2} \mathrm{H}$ in Keder spring range between $-6.24 \%$ o to $-7.14 \%$ and -32.99 to $-44.49 \%$ o respectively. Concentration of $\delta^{2} \mathrm{H}$ changed in Keder spring with increase turbidity too, from - 32.99\%o reaches to -44.49 and - 38\%o after three and six days respectively (Table 4). In the present study the isotopic composition of precipitation in the region was not determined directly, so for local atmospheric isotope composition in the study area, the results of research in western Iran (Zagros region) were used based on the approximate overlap of precipitation sampling time with precipitation in the study area (Mohammadzadeh and Amiri2020). The global line equation was also calculated based on $\delta^{18} \mathrm{O}$ concentration in Keder and Zolal springs with the following equation:

Overall atmospheric isotope line equation: $\delta^{2} \mathrm{H}=8 * \delta^{18} \mathrm{O}+10 \mathrm{R}^{2}=0.96$

Figure 11shows the distribution of $\delta^{2} \mathrm{H}$ versus $\delta 180$ in samples from Keder and Zolal springs. The location of the values for samples from both springs in October 2018 and May 2019 in the area between the global atmospheric line and the local atmospheric water line indicates that the source of recharge is rainwater. The depth of groundwater rotation is very low, especially in Keder spring. This is consistent with Mazor'sconclusion that the line for isotopic composition of karst springs tends to parallel the line for local atmospheric composition (Mazor 2004).

\subsubsection{Comparison of water composition in the two springs in April 2019}

Data from April 2019 were used to compare the hydrogeochemical status of the two springs in more detail. In water from both springs the predominant mineraliscalcium bicarbonate. Turbidity at this time point was 1.78NTUin Keder spring and 0.86NTUinZolal spring (Table 3). The difference in turbidity between the two springs is due to the different intensities of turbulent flow passing through the joints, and to differences in the structure and pathway of karst passage conduits.

The water temperature of Keder spring (turbid)was $14^{\circ} \mathrm{C}$ while the temperature at Zolal spring (no turbidity) was $18^{\circ} \mathrm{C}$. The higher temperature of Zolal spring water can be attributed to outflow from a greater depth than Keder spring. Temperaturerange of Zolal spring is stable approximately ( 15.1 and $14.9^{\circ} \mathrm{C}$ in dry and wet season), but it is variable in Keder spring ( 18.1 and $13^{\circ} \mathrm{C}$ in dry and wet season).Therefore, Keder spring recharged from snow sinkholes and it have few temperate in wet season, but Zolal spring has a stable temperature due to deep groundwater circulation (Fig. 13).lon concentrations ( $\mathrm{mg} / \mathrm{L})$ in the two springs are compared below.

$$
\text { Calcium Bicarbonate Chloride Magnesium Sodium }
$$

$\begin{array}{llllll}\text { Keder } & 16 & 60 & 9 & 2 & 1.5 \\ \text { Zolal } & 32 & 90 & 14 & 10 & 7.5\end{array}$

The higher concentrations of all ions in Zolal spring support water retention in a reservoir. Accordingly, the results of this analysis are also consistent with the results of other analyses reported above, and support the conclusion that rainwater discharged from Zolal spring remains in a karst reservoir until the next precipitation event, during which the previously stored water is discharged into the spring and is replaced with new rainwater or snowmelt. Thereafter, the turbid water has time to settle and to some extent dissolve ions present in the karst bedrock reservoir. This mechanism would explain whyZolal spring water lacks turbidity and has relatively higher concentrations of ions than the clear water from Keder spring.

AlsoData from May 2019 were used to compare the heavy metal of the two springs in more detail concentration. lon concentrations ( $\mu$ g/l) in the two springs are compared below.

$\begin{array}{lllllll} & \text { Fe } & \text { AS } & \text { ZN } & \text { Ni } & \text { Mn } & \text { Ba } \\ \text { Keder } & 434.82 & 11.27 & 22.61 & 5.45 & 2912 \\ \text { Zolal } & 62.65 & 24.06 & 4.13 & <0.28 & 6.648 .06\end{array}$

The high concentration of heavy metals in both spring shows that recharge water in the study area pass from volcanic rock and dissolved volcanic composition (Fig. 13). This research approved research of White et al (2018).

This information indicates that the concentration of arsenic in Zolal spring water is higher than inKeder spring; This might be consequence of much deeper groundwater circulation or probably because of zonality in groundwater circulation of Zolal spring around volcanic rocks (It would be related to longer and deeper groundwater flows).But concentration of ferric, copper, zinc, manganese, and nickel in Keder spring water is higher than in Zolal spring is due to dissolving of rocks and lichenin of soil and sediment, because color of around catchment is brown based on fielding observation (this is indicator for exist of ferric).

\section{Conclusion}

Page $10 / 19$ 
Karst springs in a given catchment area and aquifer may have different behavioral systems (Jiang and Guo, 2010); however, evaluation of the behavior of two springs in the present study is of interest, because despite theirproximity to one another(3 $\mathrm{m})$, they show different behaviors in terms of flow and turbidity.

The observation of a linear regime in the recession diagram, and an alpha value of 0.04 in the recession curve, indicates a karstic area with highly tectonic regions and high permeability and conduit flow.

As a result, permeability of the water flow path of the springs is so high that rainfall in the region leads to a sudden rise in discharge. Of note, the two springs show different behaviors in terms of discharge and turbidity. Maximum flow from Keder spring in May 2019 was about 3642 L/s and the water was markedly turbid, whereas maximum discharge from Zolal spring at the same time was $243 \mathrm{~L} / \mathrm{s}$ and the water was completely transparent. Turbidity in Keder spring also increases during earthquakes. However, the isotopic concentrations and bivariate plots of the most significant parameters in the samples point to the same source of water for both springs. Also, by examining the composition of water from the two springs on a smaller scale in April 2019, all the evidence indicates that the concentration of mineral ions inZolal spring water is higher than inKeder spring.

The bivariate plots of the most significant parameters and isotopic datain the samples compared here indicate that the two springs share the same source of recharge from rainfall, and in light of their close proximity and similar hydrographic behavior, these two springs likely also share the same path along part of their initial flow pathway. Part of the water from the mainspring passes through a wide channel with turbulent flow, and part of this water enters a sub-joint with a narrower joint and lower flow. Most likely, the same source of water entry in both springs is the largest sinkhole in the region, i.e. the Gachal sinkhole.

The Keder spring transports rainwater from highly-fractured paths and large karstic canals to the discharge point immediately after rain. Part of the turbidity of Keder spring can also be attributed to the movement of wall sediments within the karst duct networks (autochthonous).

The occurrence of turbidity after earthquakes also confirms this. In Zolal spring, a siphon-shaped reservoir in the path of water movement allows rainwater or snowmelt to replace water already present in the reservoir and to settle before it flows to the spring. For this reason, Zolal spring water, unlike Keder spring water, remains transparent when it rains. The results of chemical analyses supportthis conclusion too.

To further characterize the hydrogeological status of these karst springs as accurately as possible, dye tracer studies should be carried out in the region, and the concentrations of tritium and carbon 14 should be measured to determine the age of the groundwater.

\section{Declarations}

\section{Acknowledgments}

This research was supported by Tarbiat Modares University and the Water Organization of Nahavand (Iran) as a part of the requirements for the $\mathrm{PhD}$ thesis defended by Vahed Kiyani. We would also like to thank L. Vasić (Scientific Researcher in Belgrade University) for helping in first version of manuscript, Mr Jahan Bahirai for pictures of springs after the 2017 earthquake and K. Shashok (Author AID in the Eastern Mediterranean) for improving the use of English in the manuscript.

\section{References}

1. Ashjari J, Raeisi E (2006) Influences of anticlinal structure on regional flow Zagros Iran. J Cave Karst Studies 68(3):118-129

2. Amil A, Avc P, Çil A, Muhammetoğlu A, NurÖzyurt N (2020) Significance of validation for karst aquifers' vulnerability assessments: Antalya Travertine Plateau application. J Contaminant Hydrology 228:1-13

3. Amraoui F, Razack M, Bouchaou L (2003) Turbidity dynamics in karstic systems: Example ofRibaa and Bittit springs in the Middle Atlas (Morocco). J Hydrological Sciences 48(6):971-984

4. Bicalho CC, Batiot-Guilhe C, Taupin JD, Patris N, Van S (2016) A conceptual model for groundwater circulation using isotopes and geochemical tracers coupled with hydrodynamics: A case study of the Lez karst system, France J Chemical Geology 528, doi:10.1016/j.chemgeo.2017.08.014

5. Bouchaoua L, Manginb A, Chauvec. P (2002) Turbidity mechanism of water from a karstic spring: example of the A in Asser doune spring (Beni Mellal Atlas, Morocco). J Hydrology 265:34-42

6. Clark I (2015) Groundwater Geochemistry and Isotopes, first ed. CRC Press, Florida

7. Field M (2021) Groundwater sampling in karst terranes: passive sampling in comparison to event-driven sampling strategy. J Hydrogeology 29:53-65

8. Ford D, Williams P (2007) Karst Hydrogeology and Geomorphology, first ed. Wiley and Sons Press, New York Gibbs RJ (1970) Mechanisms controlling world water chemistry. J Science 170(3962):1088-1090

Page 11/19 
9. He X, Wu J, Guo W (2019) Karst Spring Protection for the Sustainable and Healthy Living: The Examples of Niangziguan Spring and Shuishentang Spring in Shanxi China. J Exposure Health 11:153-165

10. Jiang G, Guo F,. (Andreo et al (2010) Interpreting source of Lingshui spring by hydrogeological, chemical and isotopic methods, Advances in Research in Karst Media. Springer Press

11. Lacroix M, Rodet J, Wang HQ, Masséi N, Dupont JP (2000) Origine des matièresen suspension dans un système aquifer karstique: apports de la microgranulométrie (Origin of suspended matter in a karst aquifer system: contribution of microgranulometry), Sciences de la Terre et des Planèetes. 330. C R AcadSci Paris, pp 347-354

12. Malík P, Vojtková S (2012) Use of recession-curve analysis for estimation of karstification degree and its application in assessing overflow/underflow conditions in closely spaced karstic springs. J Environmental Earth Sciences 65(8):2245-2257

13. Maillet E (1905) Essaisd' Hydraulique souterraine Et fluvial. J Nature 72:25-26

14. Mazor E (2004) Chemical and Isotopic Groundwater Hydrology, Third edn. Marcel Dekker AG Press, Florida

15. Massei N, Dupont JP, Mahler BJ, Laignel B, Fournier M, Valdes D, Ogier S (2006) Investigating transport properties and turbidity dynamics of a karst aquifer using correlation, spectral, and wavelet analyses. J Hydrology 329:244-257

16. McGrory E, Holian E, Alvarez-Iglesias A, Bargary N, McGillicuddy EJ, Henry T, Daly E, Morrison L (2018) Arsenic inGroundwater in South West Ireland: Occurrence, Controls, and Hydrochemistry. J Frontiers in Environmental Science 6:154. DOI:10.3389/fenvs.2018.00154

17. Gerishman R, Herltzfeid EE, Mole M (1939) Translated by Zabihollah Mansouri, Eighteenth ed. Zarin Press, Tehran

18. Nasrabadi T, Bidabadi N, 2013.Evaluating the spatial distribution of quantitative risk and hazard level of arsenic exposure in groundwater, case study of Qorveh County,Kurdistan Iran. J. Environmental Health Science \& Engineering (In Persian). (10), pp 1-8

19. Owen DR (2016) Hydro chemical and isotopic indicators of hydrological processes within coal seam gas formations and adjacent aquifers Condamine River catchment QLD, PhD Thesis Queensland University of Technology

20. Perez BC, Lamban J, Martines SP (2013) Hydro geochemical and isotopic characterization of karstic endorheic Estana lakes (Huesca Spain). In: Andreo et al (eds) Advances in research in karst media. Springer Press, Cham

21. Pronk M, Goldscheider N, Zopfi J (2006) Dynamics and interaction of organic carbon, turbidity and bacteria in a karst aquifer system. J Hydrogeology 14(4):473-484

22. Savary M, Johannet A, Massei N, Dupont JP, Hauchard E (2021) Karst-aquifer operational turbidity forecasting by neural networks and the role of complexity in designing the model: a case study of the Yport basin in Normandy (France). J Hydrogeology 29:281-295

23. Schiperski F, Zirlewagen J, Scheytt T (2016) Transport behavior and attenuation of colloids of different density and surface charge: A karst aquifer field study. J Environmental Science Technology 50(15):8028-8035

24. Stevanović Z (2019) Hydrodynamics of karst aquifer in the field testing. International course characterization and engineering of Karst aquifer. Belgrade University. 27 May to 1 June 2019

25. Bakalowicz M (2005) Karst groundwater: a challenge for new resources. J Hydrogeology 13:148-160

26. Kiyani V (2021) Hydro geochemistry of karst springs of Zagros and Sanandaj-Sirjan zones in Nahavand area (West Iran), PhD Thesis Tarbiat Modares University

27. Karimi, Vardanjani H, Bahadorinia Sh, Ford DC (2017) An Introduction to Hypogene Karst Regions and Caves of Iran, in: (A. klimchoouk et al), Cave and Karst System of the World. Springer Press, Cham, pp. 479-494

28. Gil-Márqueza JM, Barberá JA, Andreoa B, Mudarraa M (2017) Geochemical evolution of groundwater in an evaporate karst system: Brujuelo area (Jaén, S Spain). J Procedia Earth Planetary Science 17:336-339

29. Vasić L, Živojinović D, Rajaković., Ognjanović V (2020) Hydro chemical changes and groundwater grouping data by multivariate statistical methods within one karst system: recharge-discharge zone (Eastern Serbia case study). J Carbonates Evaporites 35(15):1-13

30. White WB, Herman JS, Herman EK, Rutigliano M (2018) Karst Groundwater Contamination and Public Health, first ed. Springer Press, Cham 31. Zhang Ch (2007) Fundamentals of Environmental Sampling and Analysis, first ed. Wiley and Sons Press, New Jersey

\section{Figures}




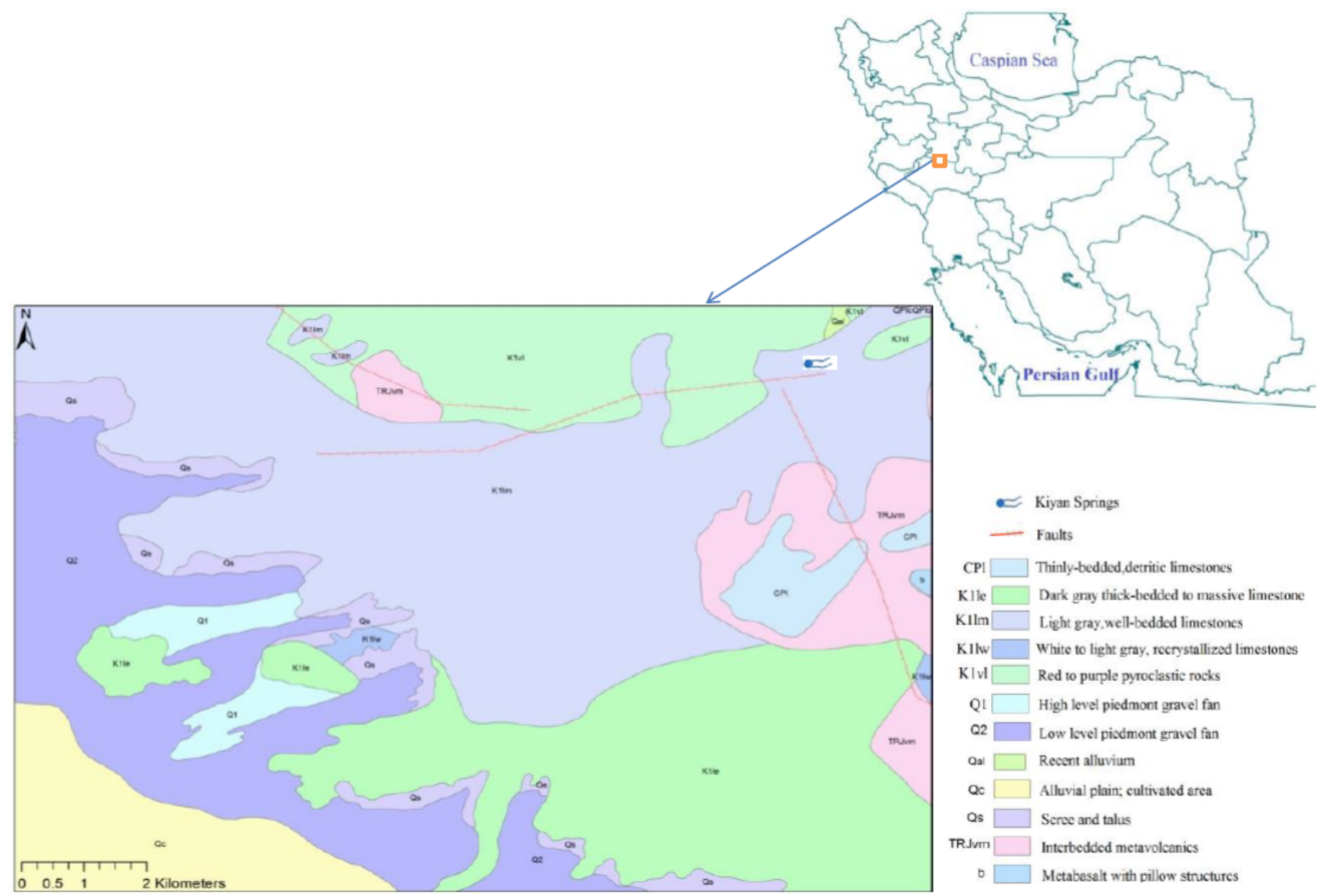

Figure 1

Position of study area in west of Iran and geological map with faults 

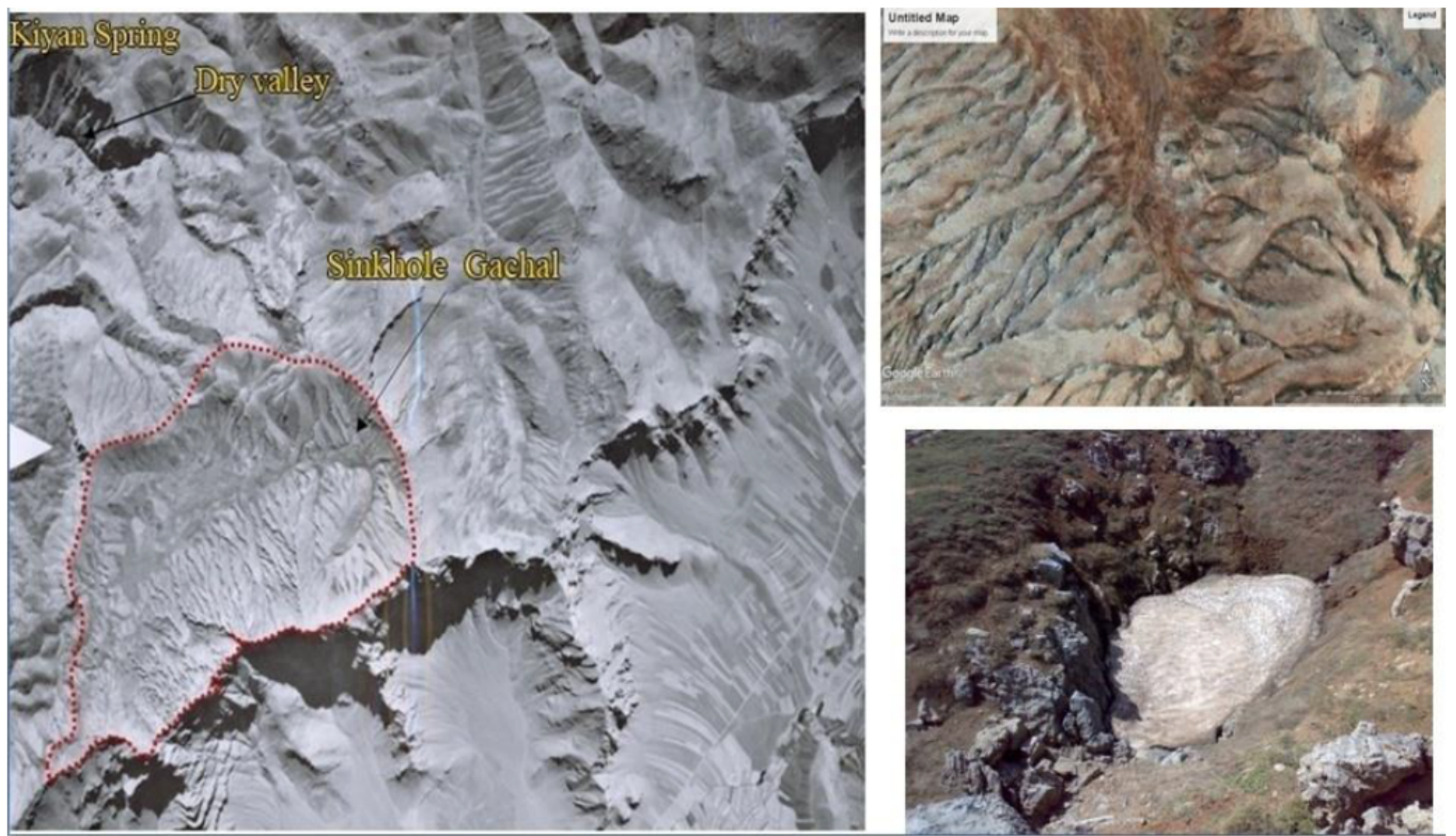

Figure 2

Photographs of sinkholes in Kiyan Mountains

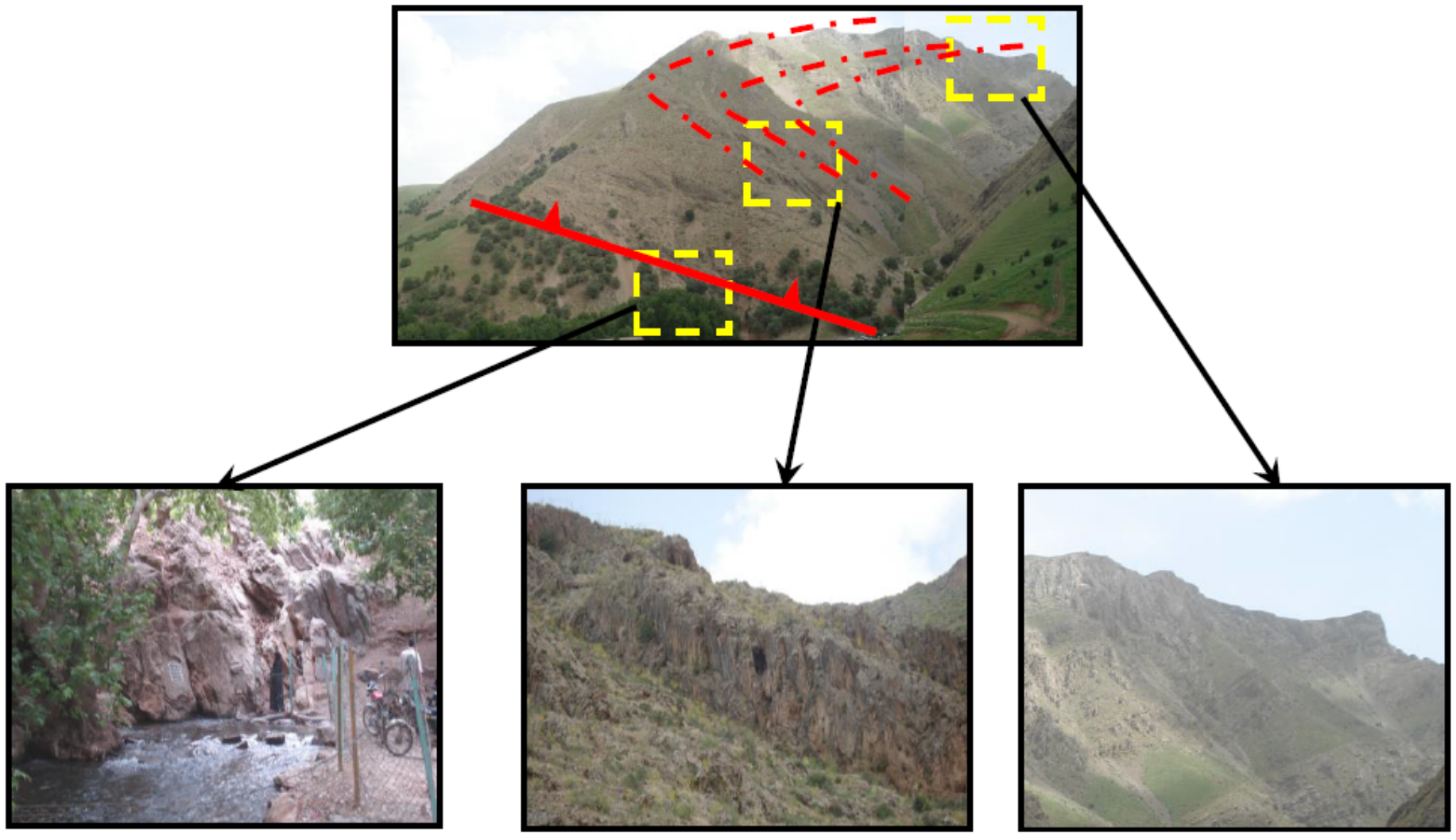

Figure 3 
Anticline Fault Mountain (above)- southern edge (down right)- northern inverse edge (down mid)- Kiyan Spring (down left)
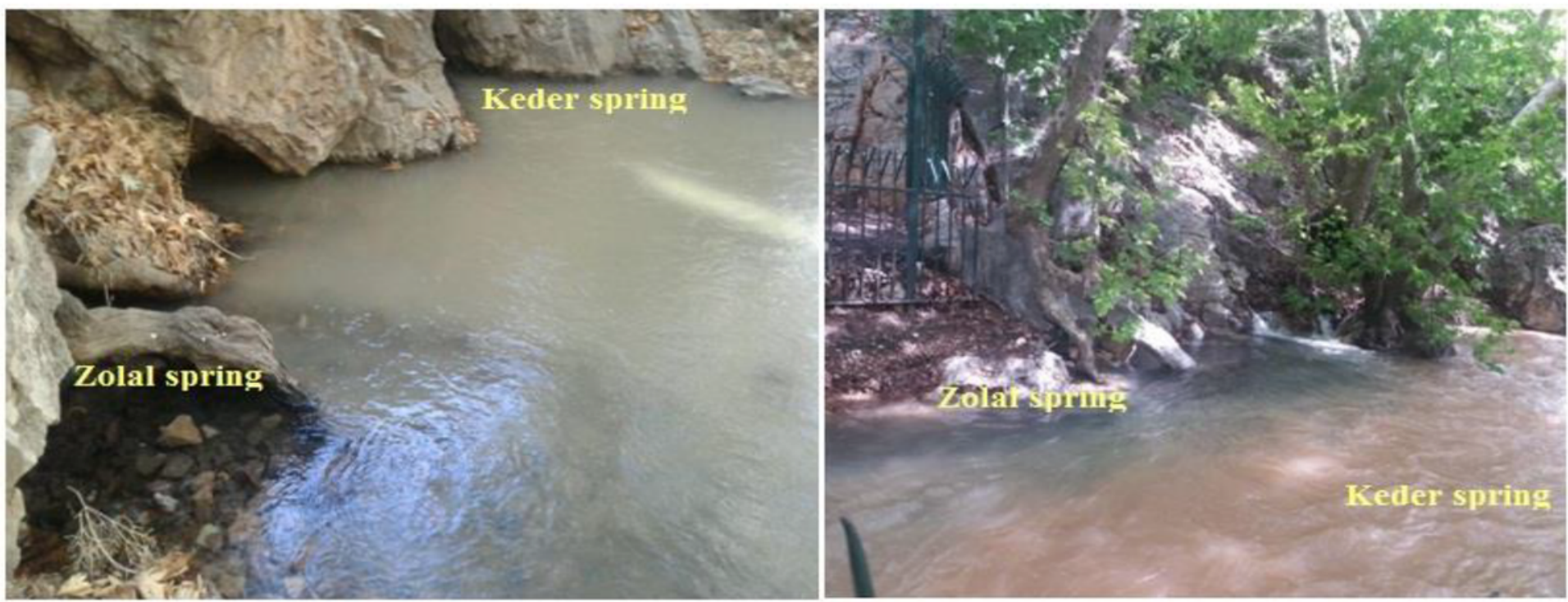

Figure 4

Zolal (clear) and Keder (turbid) springs after the 2017 earthquake (left) and 2018 storm (right)

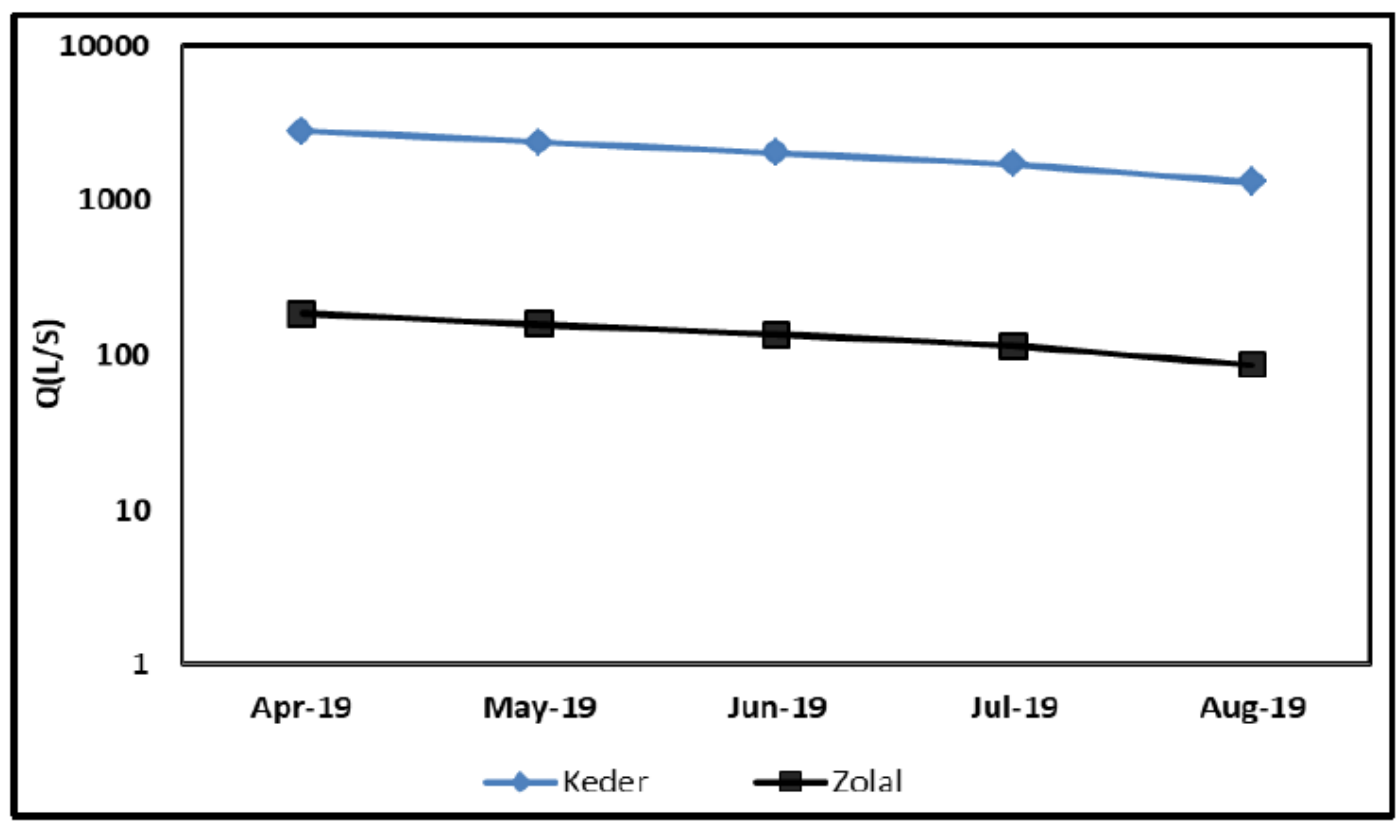

Figure 5

Recession curvesfor Zolal and Keder Springs 

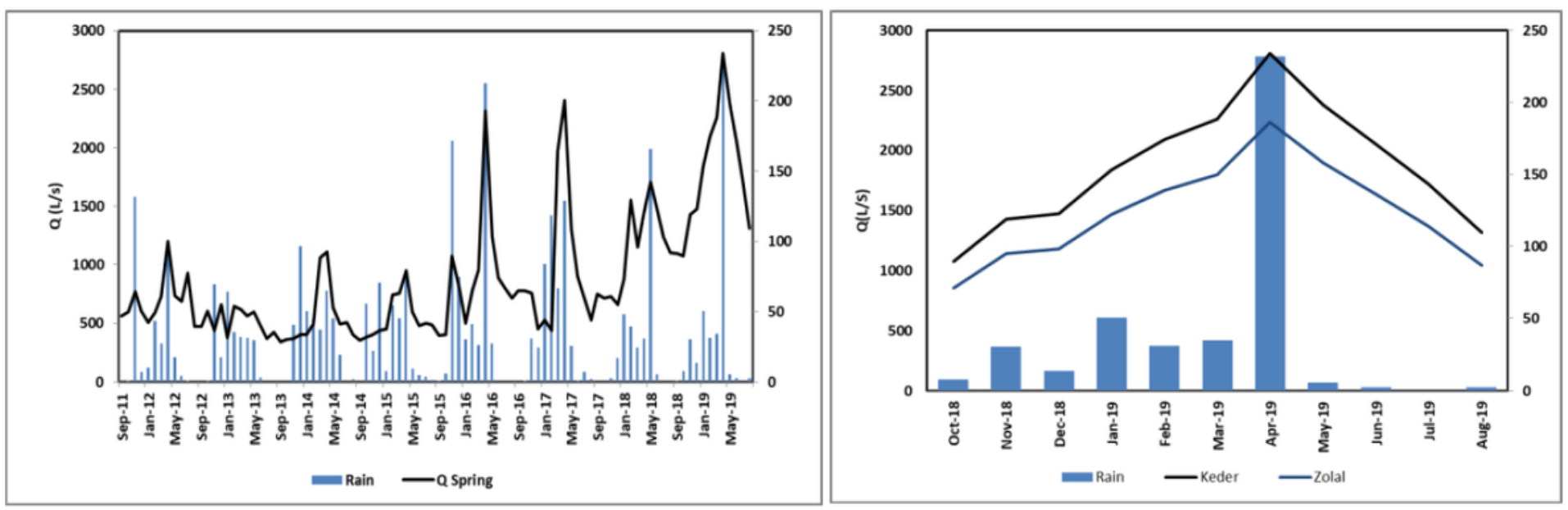

\section{Figure 6}

Hydrographs for Zolal and Keder springs

Log Turbidity (NTU)

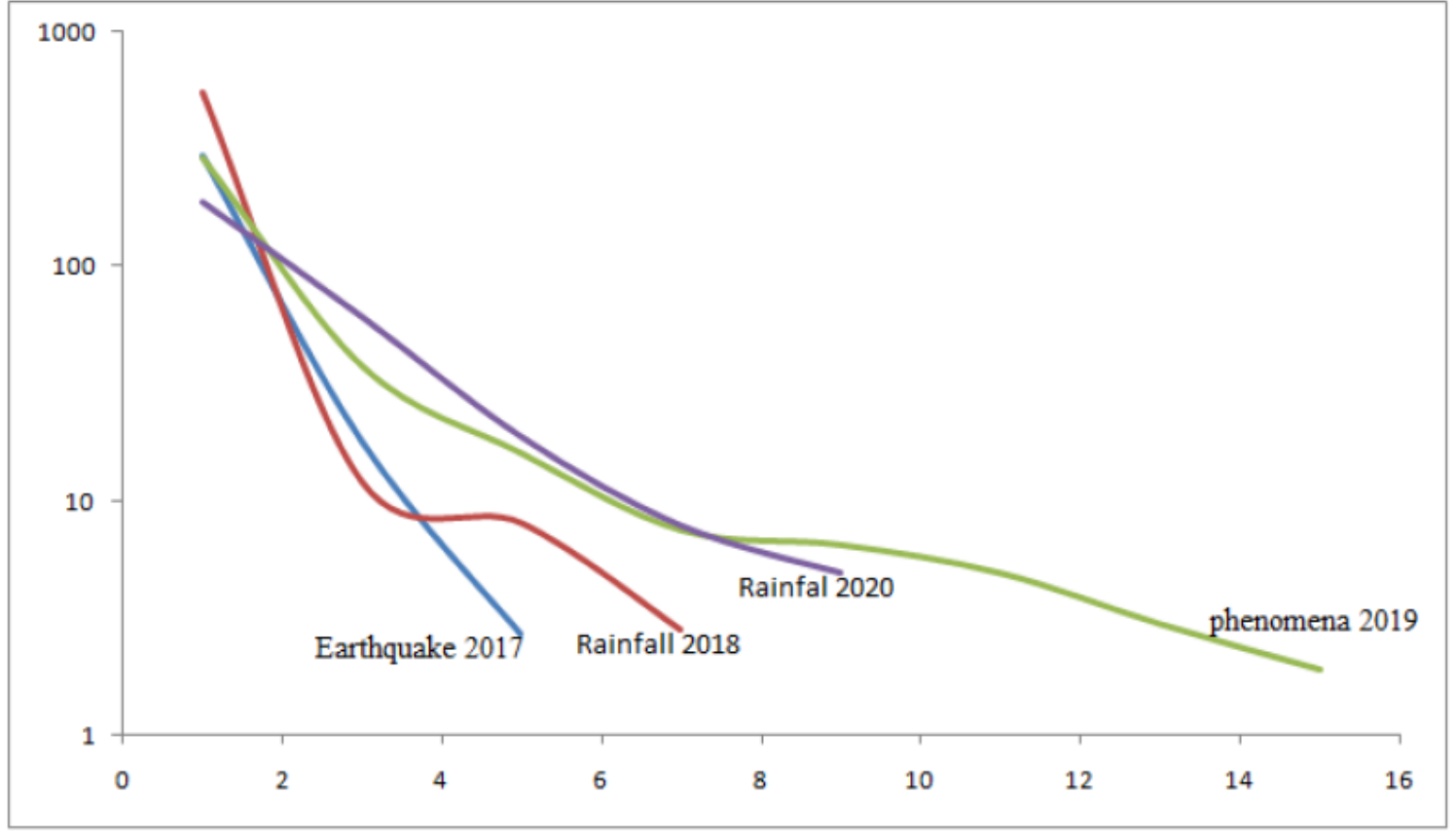

Time (day)

Figure 7

The trends of decreasing turbidity associated with the 2017 earthquake, precipitation, and the 2019 turbidity phenomenon 

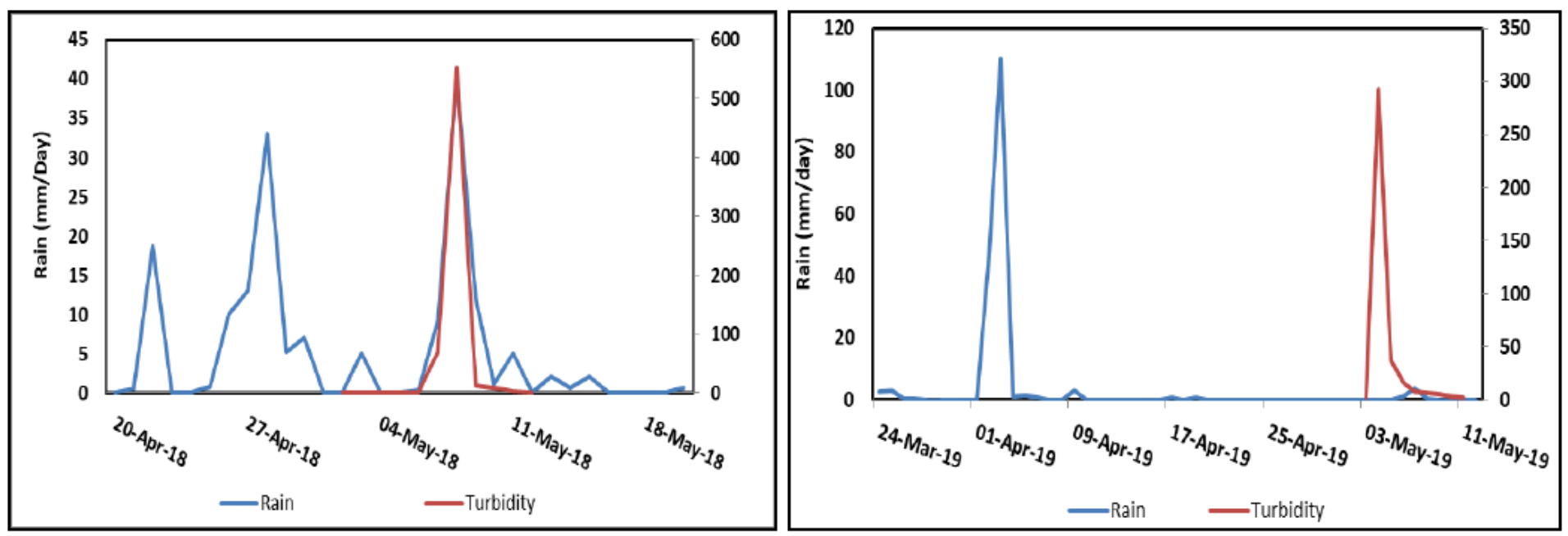

Figure 8

Daily rainfall relative to daily turbidity data

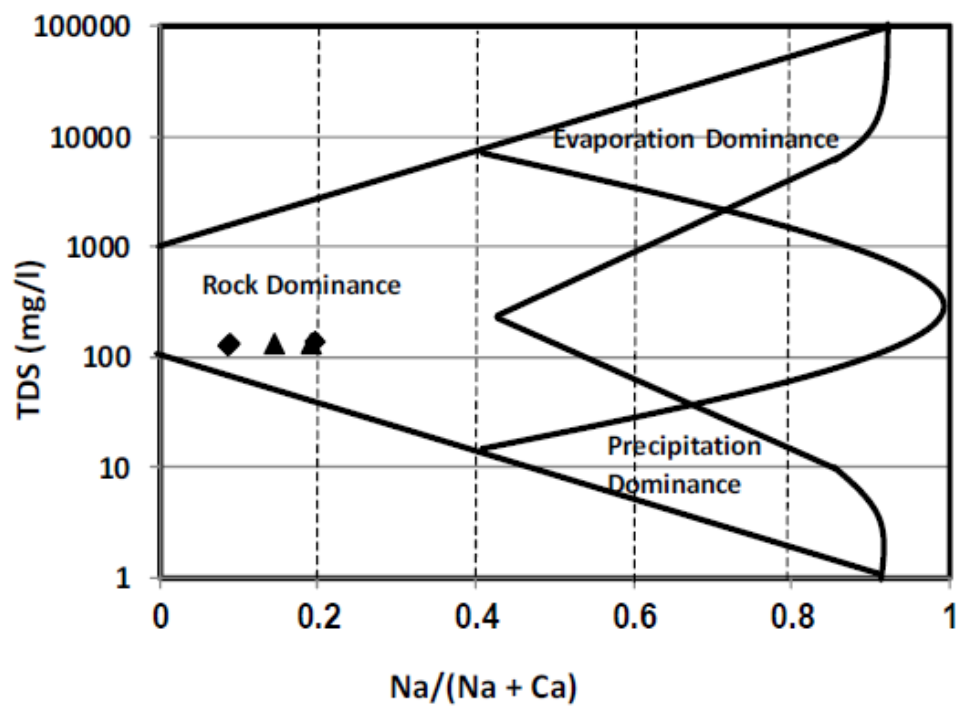

$\bullet$ Keder Spring

$\Delta$ Zolal Spring

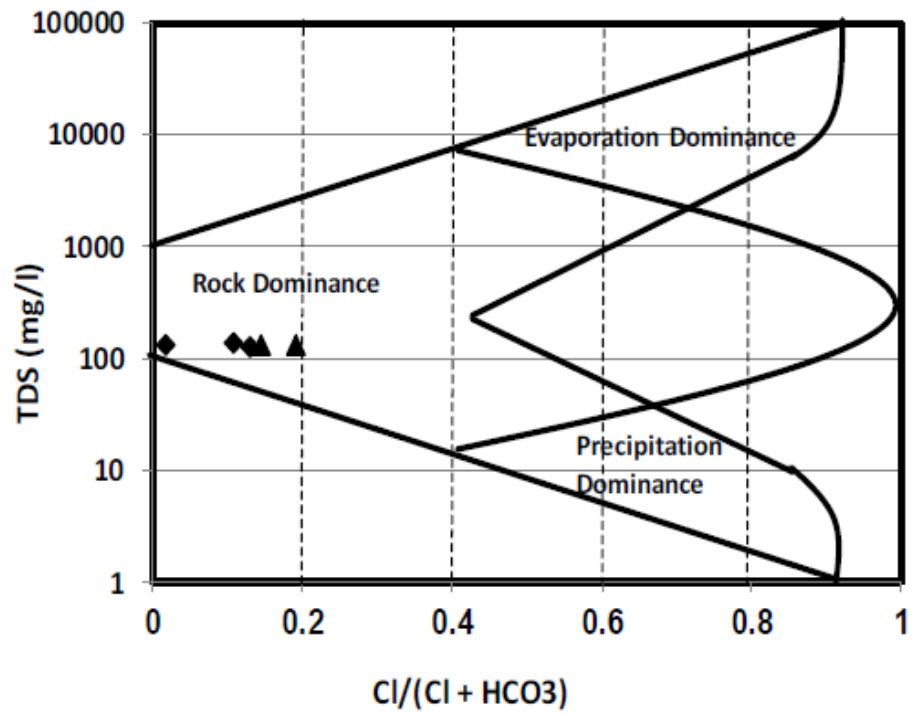

- Keder Spring

$\Delta$ Zolal Spring

Figure 9

Gibbs diagram for Keder and Zolal springs 

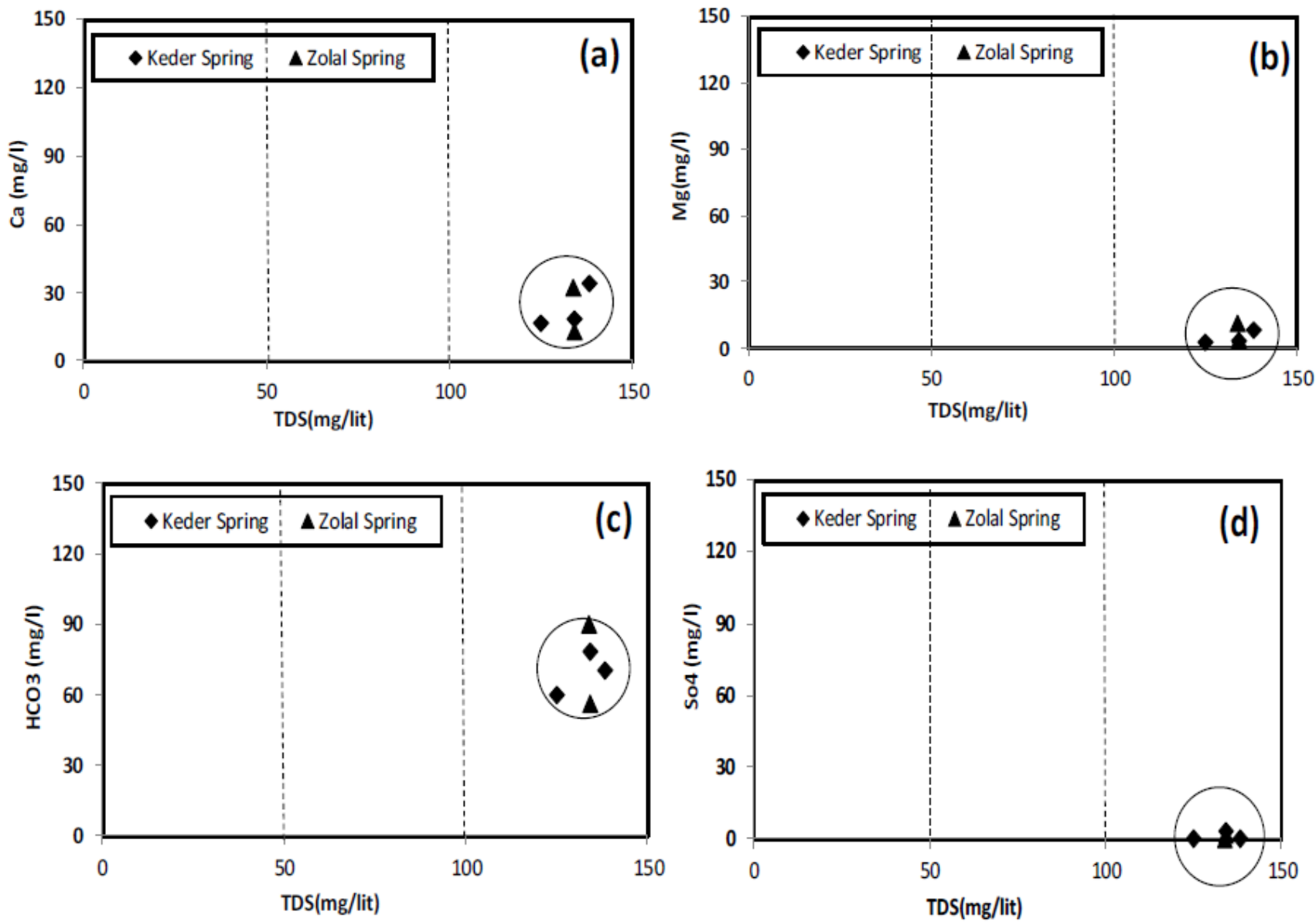

Figure 10

Bivariate plots of the most significant parameters of spring samples

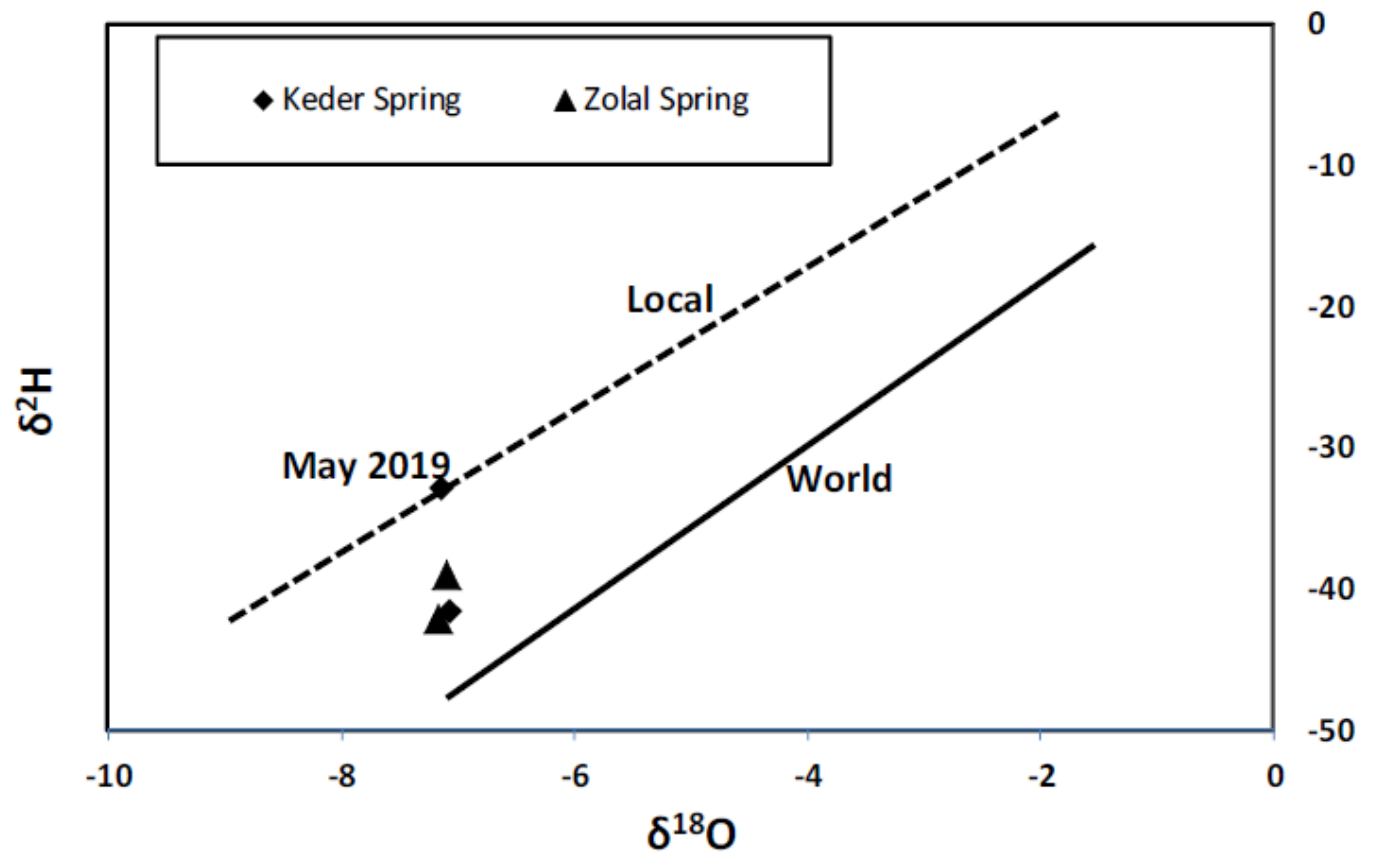

Figure 11

Distribution diagram of $\delta 2 \mathrm{H}$ vs. $\delta 180$ for Keder and Zolal springs 


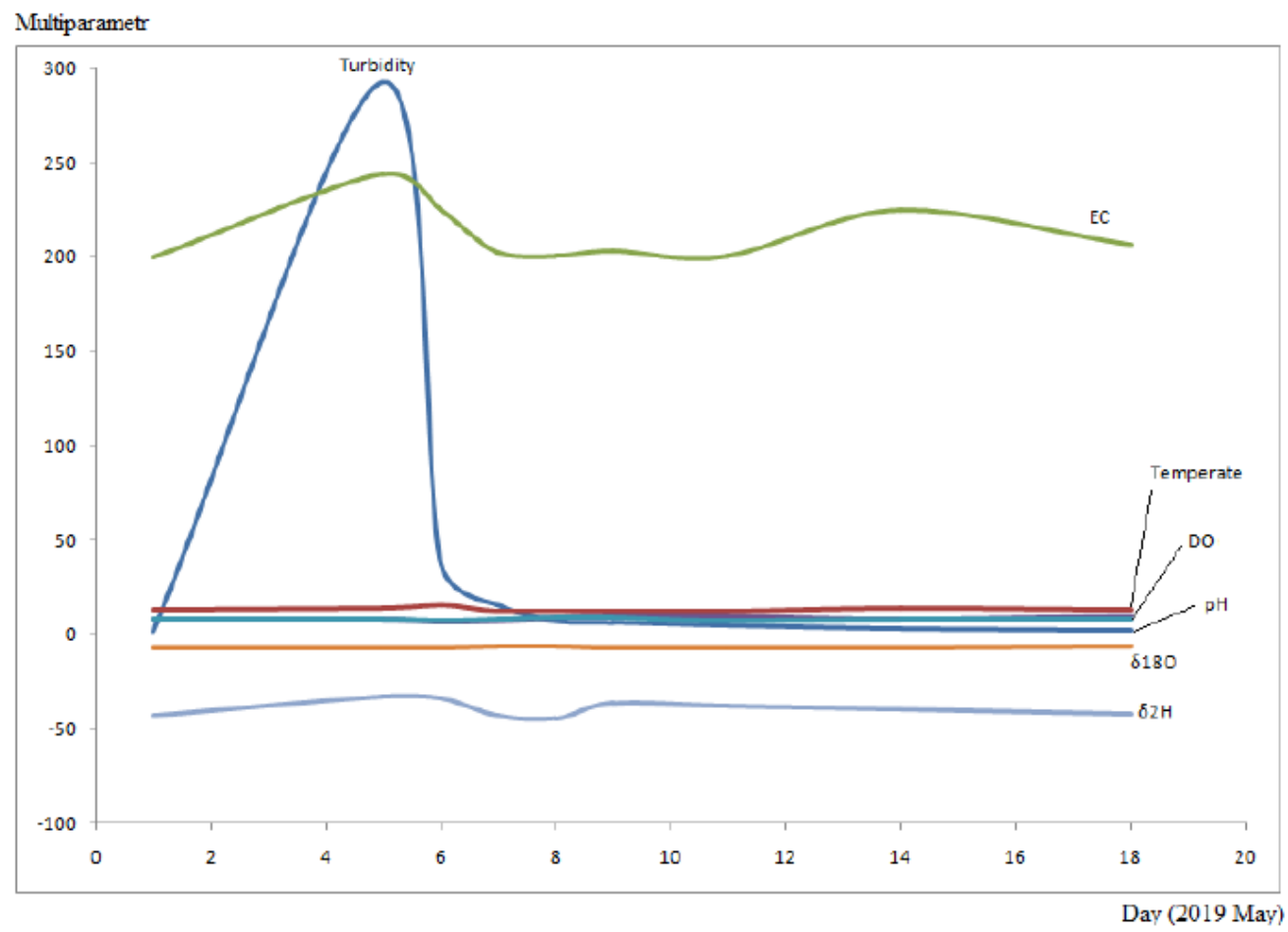

Figure 12

Multiparametric profiles EC, T, pH, DO, 1180 and $\delta 2 \mathrm{H}$ of Keder spring phenomena 2019

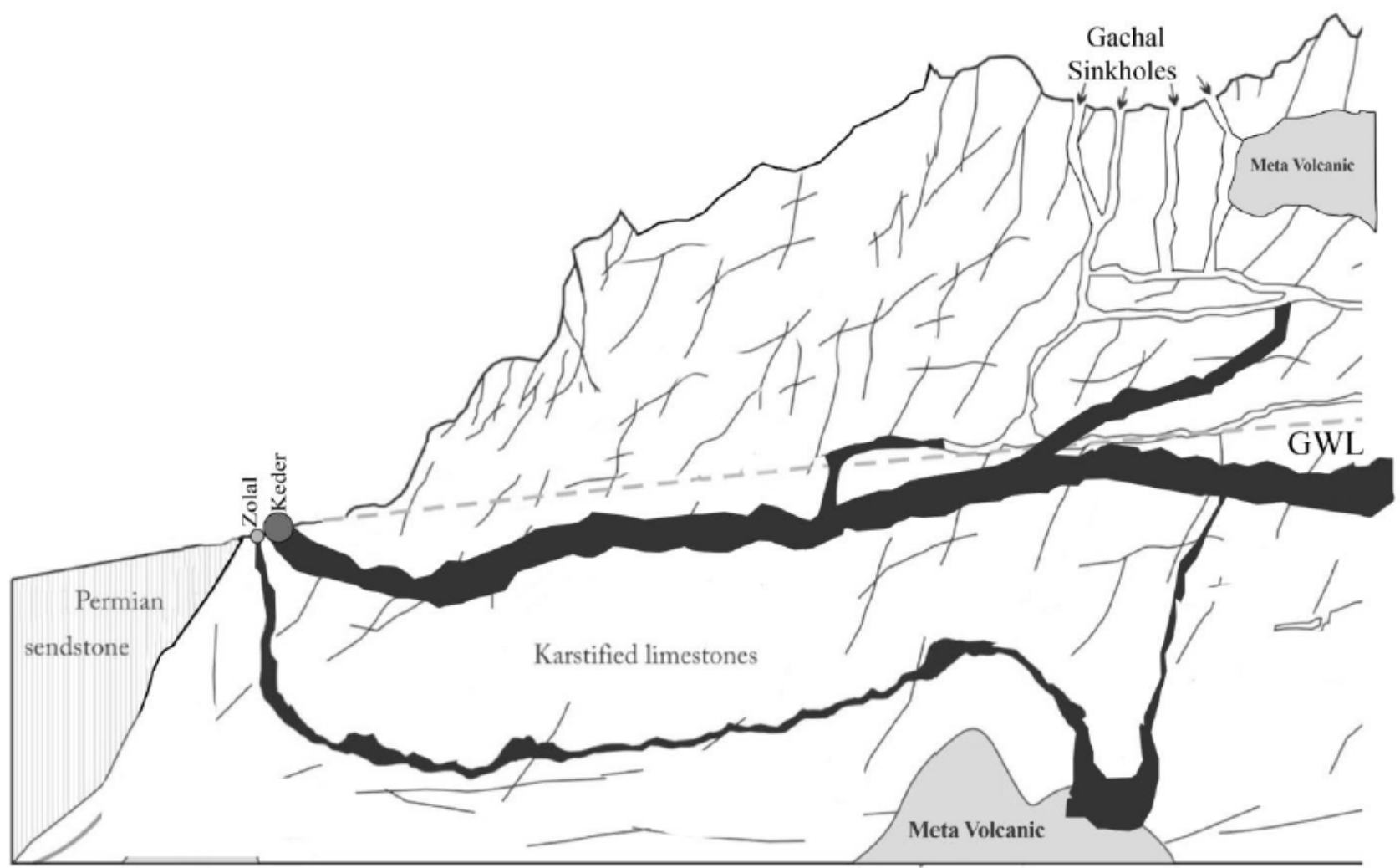

Figure 13

Schematic overview of groundwater circulation in Keder and zolal spring 